\title{
АНАЛІЗ КОНКУРЕНТОСПРОМОЖНОСТІ СІЛЬСЬКОГОСПОДАРСЬКИХ КОМПЛЕКСІВ УКРАЇНИ ТА ПОЛЬЩІ1
}

\author{
Голишева Євгенія Олексіївна \\ кандидат економічних наук, доцент \\ Сумський національний аграрний університет (м.Суми, Україна) \\ ORCID: 0000-0001-7788-9897 \\ ievgeniia.golysheva@snau.edu.ua
}

У статті проаналізовано стан аграрного сектору України та Польщі за такими показниками, як сільськогосподарські угіддя в абсолютних та відносних значеннях, сільське господарство, лісове господарство та додана вартість риболовлі. Крім того, враховувалися кількість сільськогосподарських робітників та їхня заробітна плата в місцевих валютах та в еквіваленті євро, динаміка цін на основні сільськогосподарські продукти та структура експорту-імпорту сільськогосподарської продукції. На основі аналізу було висвітлено основні особливості українського аграрного комплексу та тендениії його розвитку. Дослідження ляже в основу аналізу конкурентоспроможності сільськогосподарських підприємств України.

Ключові слова: сільськогосподарський продукт, сільськогосподарський ринок, Україна, Польща, сільськогосподарське підприємство.

DOI: https://doi.org/10.32845/bsnau.2019.1.6

Вступ. У сучасних економічних умовах успіх національної економіки залежить від послідовних управлінських дій її лідерів та ефективного розвитку окремих її суб'єктів господарювання. Кожна країна обирає власну економічну сфреру, у якій може досягти найвищих результатів. Така область для України - ринок сільськогосподарської продукції. Україна вже не перший рік $є$ одним із провідних експортерів пшениці, ячменю, кукурудзи, вівса, жита та олійних культур. Родючі землі та помірний клімат дають аграрним підприємствам сильні конкурентні переваги. Тому так важливо допомогти реалізувати потенціал українських аграрних підприємств.

Польща має схожі особливості території та клімату. 3 часу асоціації та членства в ЄС ця країна пройшла значні етапи в розвитку економіки. Хоча сьогодні значну частину ВВП займає виробництво товарів з високою доданою вартістю, також Польща є передовим світовим та європейським експортером аграрної продукції (наприклад, входить до ТОП10 експортерів заморожених овочів). Тому порівняння з польським аграрним комплексом є актуальним для аналізу конкурентоспроможності українських аграрних підприємств.

Аналіз останніх досліджень і публікацій. Аграрний сектор та аграрний ринок України часто стають об'єктом досліджень вітчизняних вчених-економістів, оскільки аграрний сектор дає значну частину ВВП України. Можна виділити

праці деяких вчених, які присвячені аналізу діяльності аграрних підприємств, інноваційним аспектам управління, аналізу аграрного ринку України, виділенню тенденцій його розвитку, порівнянню з Польщею та характеристиці процесу асоціації з ЄC: І. Бурячек (2018), Ю. Данько (2016), В. Корчун (2013), С. Ковальчук (2016), І. Салкова (2016), О. Захарчук (2015), Т. Зінчук (2016) та інші.

Для подальшого аналізу конкурентоспроможності аграрних підприємств України необхідно оновити аналіз аграрного сектору України. Тому метою статті $€$ аналіз основних показників аграрних комплексів України та Польщі, висвітлення основних особливостей та тенденцій розвитку аграрного сектору України.

\section{Основний матеріал.}

1. Загальні показники сільськогосподарських галузей України та Польщі.

Україна та Польща - країни Європи з досить великими територіями, значна частина яких зайнята землями сільського господарства. За даними Світового банку (табл. 1), сільськогосподарські угіддя в Польщі в 2016 році становили 143740 кв. км або майже 47\% всієї території країни. В Україні для сільськогосподарських потреб виділяється більше земель - 415150 кв. км або майже $72 \%$ площі.

Таблиця 1 - Показники використання земель під аграрні потреби у 2013-2016 роках (Україна та Польща)

\begin{tabular}{|c|c|c|c|c|c|}
\hline & Показники & 2013 & 2014 & 2015 & 2016 \\
\hline \multirow{5}{*}{ 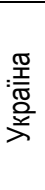 } & Сільськогосподарські угіддя (кв. км) & 415260 & 415110 & 415080 & 415150 \\
\hline & Сільськогосподарські угіддя (у \% до загальної площі території країни) & 71,68 & 71,66 & 71,65 & 71,67 \\
\hline & Площа посівів під зернові (кв. км) & 155486,0 & 144020,0 & 143956,1 & 140167,0 \\
\hline & Площа посівів під зернові (у \% до загальних сільськогосподарських угідь) & 37,44 & 34,69 & 34,68 & 33,76 \\
\hline & Урожайність зернових (кг на гектар) & 4031,2 & 4400,7 & 4141,8 & 4652,4 \\
\hline \multirow{5}{*}{ 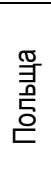 } & Сільськогосподарські угіддя (кв. км) & 144100 & 144240 & 143710 & 143740 \\
\hline & Сільськогосподарські угіддя (у \% до загальної площі території країни) & 47,06 & 47,11 & 46,93 & 46,94 \\
\hline & Площа посівів під зернові (кв. км) & 74794,5 & 74849,6 & 75118,5 & 74624,2 \\
\hline & Площа посівів під зернові (у \% до загальних сільськогосподарських угідь) & 51,90 & 51,89 & 52,27 & 51,92 \\
\hline & Урожайність зернових (кг на гектар) & 3804,4 & 4268 & 3727,8 & 3999,9 \\
\hline
\end{tabular}

Джерело: власна розробка на основі даних Світового банку.

\footnotetext{
1 Робота виконана за рахунок бюджетних коштів МОН України, наданих на виконання науково-дослідної теми «Управління конкурентоспроможністю підприємств на засадах інноваційного маркетингу» (№ ДР 0119U100250)
}

Вісник Сумського національного аграрного університету

Серія «Економіка і менеджмент», випуск 1 (79), 2019 
Необхідно також зазначити, що для виробництва зернових використовується майже $52 \%$ сільськогосподарських угідь Польщі. До зернових культур належать пшениця, рис, кукурудза, ячмінь, овес, жито, просо, гречка та змішані зернові. Зернові культури, зібрані для сіна або для їжі, кормів або силосу, а також ті, які використовуються для випасу худоби, виключаються. В Україні цей відсоток значно менший - лише 34\% сільськогосподарських земель. Хоча в абсолютних значеннях українській показник вдвічі більший, ніж польській (140167 кв. км - в Україні та 74624,2 кв. км - у Польщі). Крім того, урожайність зернових в Україні постійно зростає. У 2016 р. вона становила 4652,4 ц/га, тоді як у 2012 р. це показник становив 3157,1 ц/га. У Польщі темпи приросту врожаю зернових не такі значні, але також мають тенденцію до зростання. Урожай зернових, що вимірюється кілограмами на гектар заготовленої землі, включає пшеницю, рис, кукурудзу, ячмінь, овес, жито, просо, гречку та змішані зерна. Дані про виробництво зернових культур стосуються сільськогосподарських культур, зібраних лише для сухого зерна. Зернові куль- тури, які заготовлені для сіна або зібрані в недозрілому вигляді для кормів або силосу, і ті, які використовуються для випасу, не включаються.

Це дає Україні можливість залишатися світовим експортером зернових. I в той же час нарощувати інші напрямки виробництва аграрної продукції на решті сільськогосподарських угідь.

Розглянемо показники ефективності аграрної діяльності країн (таблиця 2). Наприклад, додана вартість на одного працівника (це міра продуктивності праці) - додана вартість на одиницю вкладеної продукції. Додана вартість означає чистий результат сектора після сумування всіх результатів та віднімання проміжних вкладень. Дані вимірюються у доларах США за курсом 2010 року. Так, в Україні цей показник у 2017 році становить 4801,36 дол., що набагато вище аналогічного показника у 2013 році (3273,73 дол.). У Польщі цей показник вищий, ніж в Україні, і становить 6736,73 дол. Однак його зростання не настільки значне порівняно з 2013 роком (6305,74 дол.).

Таблиця 2 - Показники використання землі під аграрні потреби у 2013-2017 роках (Україна та Польща)

\begin{tabular}{|c|c|c|c|c|c|c|}
\hline & Показники & 2013 & 2014 & 2015 & 2016 & 2017 \\
\hline \multirow{2}{*}{  } & $\begin{array}{l}\text { Сільське господарство, лісове господарство та } \\
\text { рибальство, додана вартість на одного працівника } \\
\text { (постійні долари США } 2010 \text { року) }\end{array}$ & 3273,73 & 4782,80 & 4423,50 & 4829,23 & 4801,36 \\
\hline & $\begin{array}{l}\text { Сільське господарство, лісове господарство та } \\
\text { рибальство, додана вартість (\% у ВВП) }\end{array}$ & 8,79 & 10,15 & 12,06 & 11,73 & 10,23 \\
\hline \multirow{2}{*}{$\begin{array}{l}\frac{0}{3} \\
\text { 总 } \\
\text { 은 }\end{array}$} & $\begin{array}{l}\text { Сільське господарство, лісове господарство та } \\
\text { рибальство, додана вартість на одного працівника } \\
\text { (постійні долари США } 2010 \text { року) }\end{array}$ & 6305,74 & 6488,70 & 5842,36 & 6442,20 & 6736,73 \\
\hline & $\begin{array}{l}\text { Сільське господарство, лісове господарство та } \\
\text { рибальство, додана вартість (\% у ВВП) }\end{array}$ & 2,87 & 2,61 & 2,20 & 2,38 & 2,78 \\
\hline
\end{tabular}

Джерело: власна розробка на основі даних Світового банку.

Якщо говорити про ту частину ВВП, яку займає сільське господарство, лісове господарство та рибальство, то в Польщі - це 2,78 \% від ВВП, тоді як в Україні - 10,23\% у 2017 році. Польщі

2. Характеристика аграрних комплексів України та

У цьому пункті розглянемо детальніше аграрні комплекси України та Польщі. Для аналізу були використані офріційні дані Державної служби статистики вищевказаних країн.

Середня кількість працівників у сільськогосподарському секторі України в 2017 році становила 405,4 тис. осіб. Це 5 \% від загальної кількості працюючих в Україні. У Польщі набагато менше працівників зайнято в аграрному секторі. Середня кількість працівників у сільському господарстві становила 86 тис. осіб на кінець 2017 року, 87 тис. осіб - на кінець 2018 р. Це 0,9 \% від загальної кількості працюючих осіб у Польщі.

На кінець 2018 року середня зарплата в Україні в аграрному секторі становила 7617 грн або приблизно 237,6 євро (за курсом Національного банку України на 03.12.3018). На кінець 2017 року вона становила 5761 грн. Так, за рік зарплата сільськогосподарських працівників зросла на $32,2 \%$. Це $72 \%$ у 2018 році та 81,1\% у 2017 році від середньої зарплати по країні. Він також нижчий на 34,1\% у 2018 році та на
24,5\% у 2017 році порівняно із зарплатою в промисловості.

У Польщі рівень заробітної плати в аграрному секторі значно вищий як порівняно з Україною, так і порівняно із середньою зарплатою в країні. Середня зарплата за 9 місяців 2017 року становила 4836,22 злотих (за весь 2017 рік вона становила 5034,20 злотих, у 2016 році - 4847,60 злотих). За 9 місяців 2018 року - 5072,61 злотих або 1180,94 євро (за курсом Національного банку Польщі на 03.09.2018). Це становить $113 \%$ у 2017 році та $111 \%$ у 2018 році від середньої зарплати по країні. Середня заробітна плата в аграрному секторі Польщі перевищує виплати в промисловості (на 8\% - у 2017 році та на $5,5 \%$ - у 2018 році).

Розглянемо зміну цін у динаміці основних зернових культур: пшениці та жита. Середні ціни закупівлі на пшеницю та жито в національній валюті за тонну в 2012-2017 роках для України (рис. 1) та у 2012-2018 рр. для Польщі (рис. 2) наведені нижче. Також на рисунках відображено динаміку зміни ціни. Як видно коливання цін в Україні більш значні, ніж у Польщі. Також у Польщі спостерігається тенденція до підвищення ціни, тоді як в Україні - до зниження. Серед інших факторів це можна пояснити великими врожаями зернових культур, які спостерігаються останніми роками в Україні. 


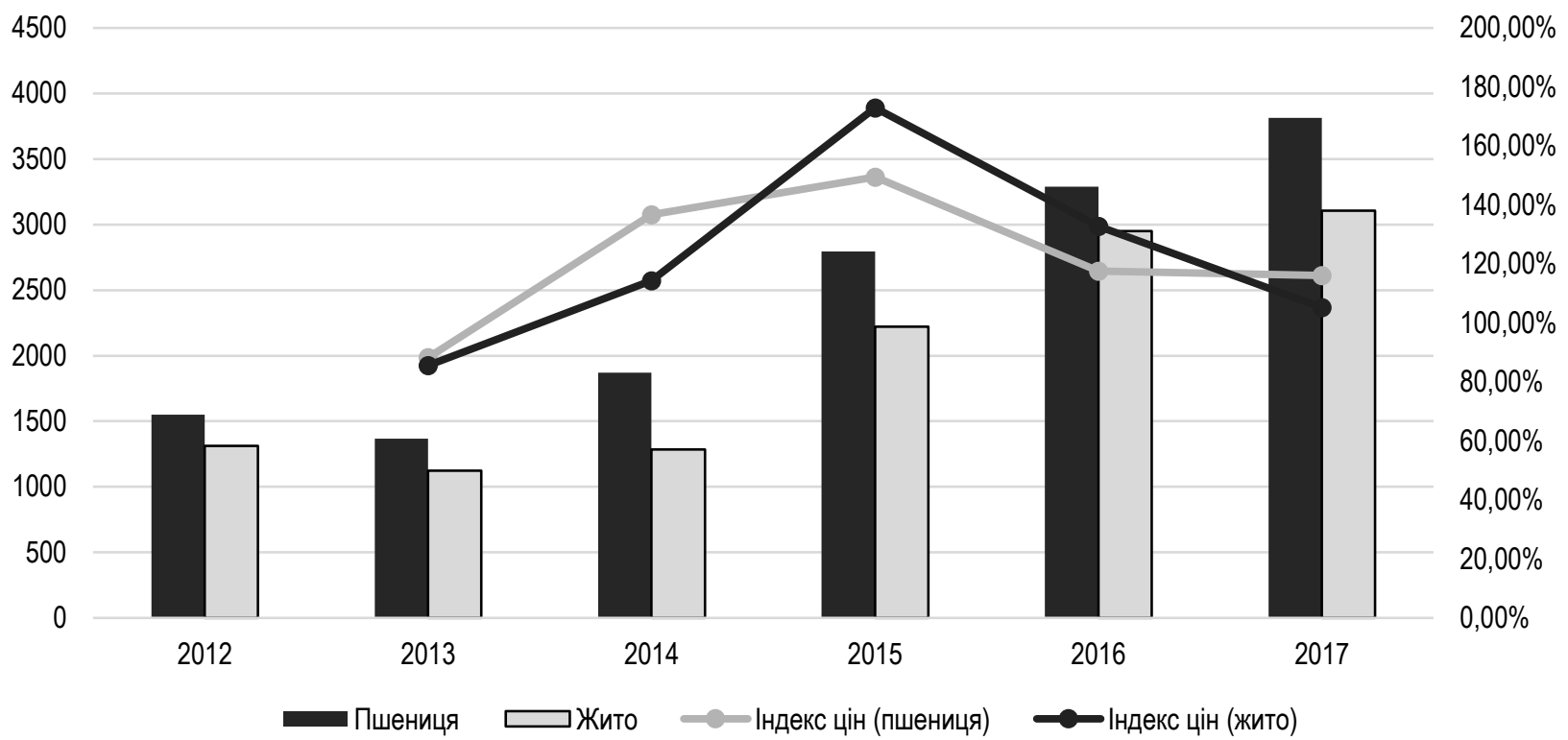

Рис. 1 - Середні закупівельні ціни та індекс цін на пшеницю та жито у 2012-2017 рр. (Україна), у грн за тонну Джерело: власна розробка на базі даних Державної служби статистики України

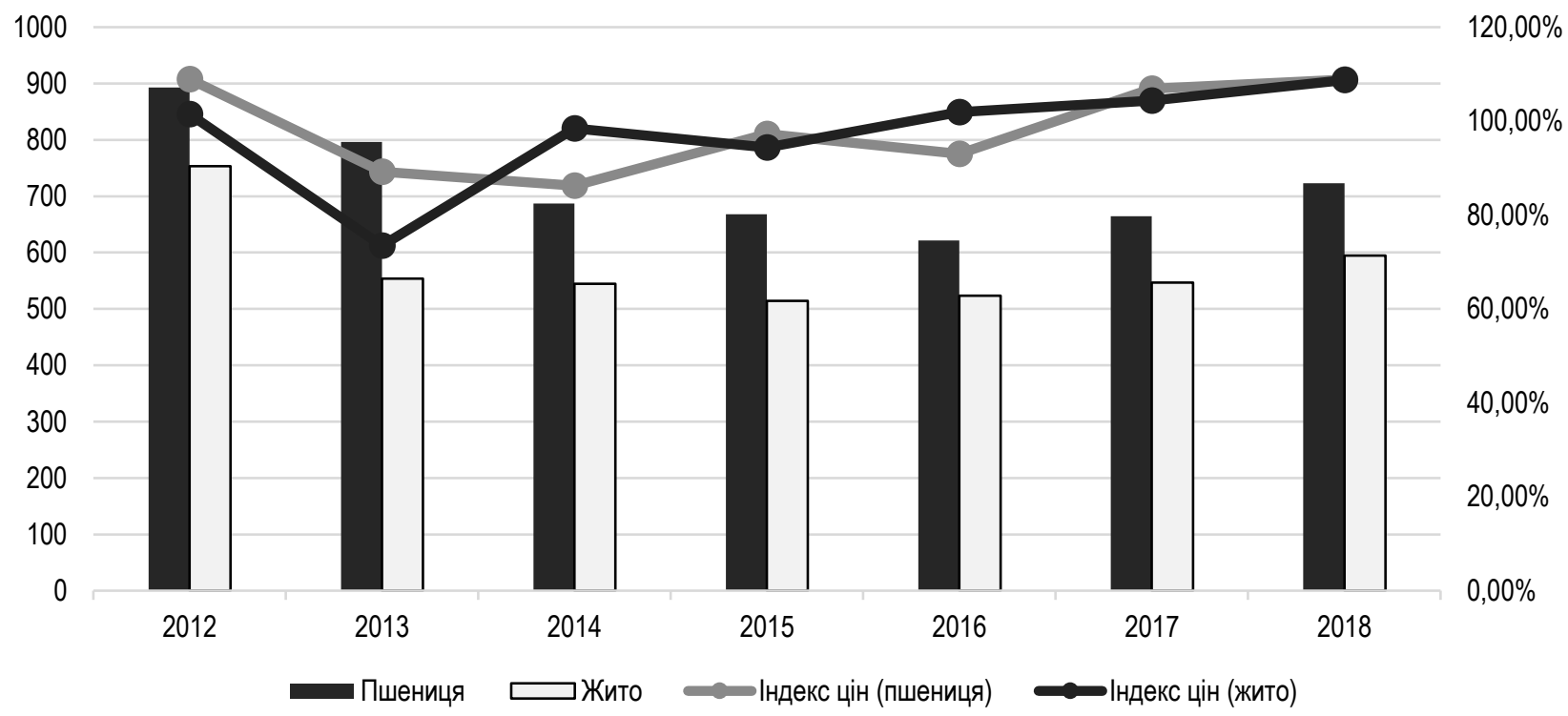

Рис. 2 - Середні закупівельні ціни та індекс цін на пшеницю та жито у 2012-2018 (Польща), у злотих за тонну Джерело: власна розробка на базі даних Центрального статистичного офрісу Польщі

Якщо говорити про тваринництво, то цінові тенденції в двох країнах також різноманітні. В Україні спостерігається значне коливання цін на велику рогату худобу, але стабільне зростання цін на коров'яче молоко в останні роки (рис. 3). У
Польщі, навпаки, ціни на велику рогату худобу відносно стабільні, а ціна молока значно знизилася з 2017 по 2018 рік (рис. 4). 




Рис. 3 - Середні закупівельні ціни та індекс цін на велику рогату худобу та молоко в 2012-2017рр. (Україна), у грн за тонну

Джерело: власна розробка на базі даних Державної служби статистики України

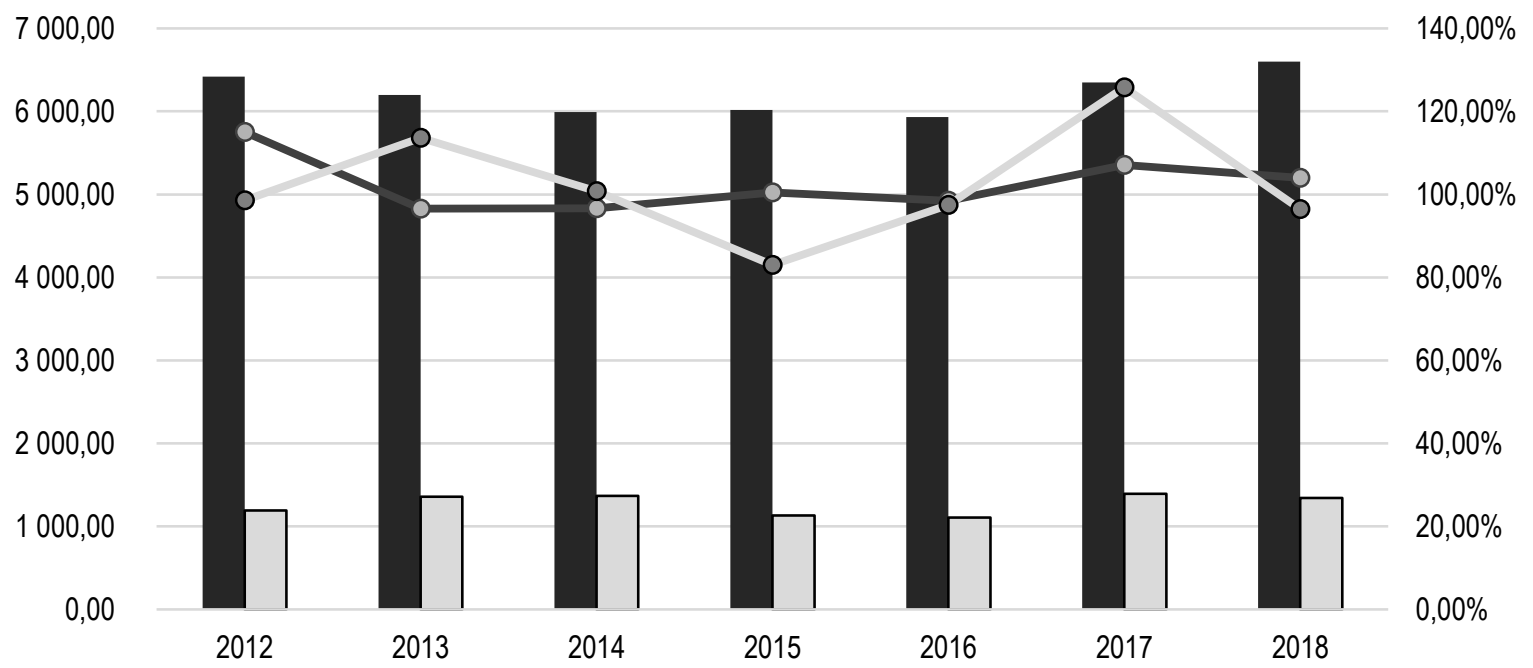

Велика рогата худоба $\square$ Молоко $\quad$ - - нндекс цін (худоба) $\quad$ - Індекс цін (молоко)

Рис. 4 - Середні закупівельні ціни та індекс цін на велику рогату худобу та молоко в 2012-2018 рр. (Польща), у злотих за тонну

Джерело: власна розробка на базі даних Центрального статистичного офрісу Польщі

Загальна динаміка цін на основні сільськогосподарські продукти у 2013-2017 рр. наведена в таблиці 3. Також подано приблизні ціни на сільськогосподарську продукцію у перерахунку на євро у 2017 році. Як ми бачимо, у Польщі ціни на сільськогосподарську продукцію вищі. У цілому у сукупності різних факторів це пояснюється також вищою оплатою праці сільськогосподарських працівників у країні, як зазначено вище. 
Таблиця 3 - Динаміка цін на основні сільськогосподарські продукти у 2013-2017рр. (Україна та Польща)

\begin{tabular}{|c|c|c|c|c|c|c|c|}
\hline & \multirow[t]{2}{*}{ Продукція } & \multicolumn{5}{|c|}{ Індекс цін, \% } & \multirow[t]{2}{*}{$\begin{array}{c}\text { Ціни в євро за } \\
\text { тонну }\end{array}$} \\
\hline & & 2013 & 2014 & 2015 & 2016 & 2017 & \\
\hline \multirow{4}{*}{ 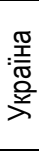 } & Пшениця & $88,25 \%$ & $136,74 \%$ & $149,47 \%$ & $117,58 \%$ & $116,02 \%$ & 125,55 \\
\hline & Жито & $85,58 \%$ & $114,33 \%$ & $172,91 \%$ & $132,76 \%$ & $105,29 \%$ & 102,24 \\
\hline & Худоба & $95,87 \%$ & $121,98 \%$ & $139,58 \%$ & $102,28 \%$ & $141,71 \%$ & 1047,90 \\
\hline & Молоко & $126,36 \%$ & $106,67 \%$ & $121,15 \%$ & $125,64 \%$ & $132,45 \%$ & 238,09 \\
\hline \multirow{4}{*}{$\begin{array}{l}\text { O } \\
\text { 总 } \\
\text { 은 }\end{array}$} & Пшениця & $89,20 \%$ & $86,24 \%$ & $97,26 \%$ & $93,01 \%$ & $106,89 \%$ & 156,49 \\
\hline & Жито & $73,47 \%$ & $98,43 \%$ & $94,37 \%$ & $101,87 \%$ & $104,37 \%$ & 128,76 \\
\hline & Худоба & $96,57 \%$ & $96,61 \%$ & $100,50 \%$ & $98,50 \%$ & $107,08 \%$ & 1495,63 \\
\hline & Молоко & $113,58 \%$ & $100,73 \%$ & $83,00 \%$ & $97,48 \%$ & $125,79 \%$ & 327,51 \\
\hline
\end{tabular}

Джерело: власна розробка на базі даних Державної служби статистики України та Центрального статистичного офрісу Польщі

Україна та Польща активно експортують сільськогосподарську продукцію на європейський та світовий ринки. Структура імпорту та експорту України у 2017 році подана на рис. 5. Як бачимо, експорт переважає над імпортом. Це пояс- нюється тим, що українські сільськогосподарські підприємства майже повністю задовольняють внутрішній попит населення. Продукція преміум-сегменту та ті культури, які через кліматичні особливості України не можуть вирощуватись на її території, імпортуються.

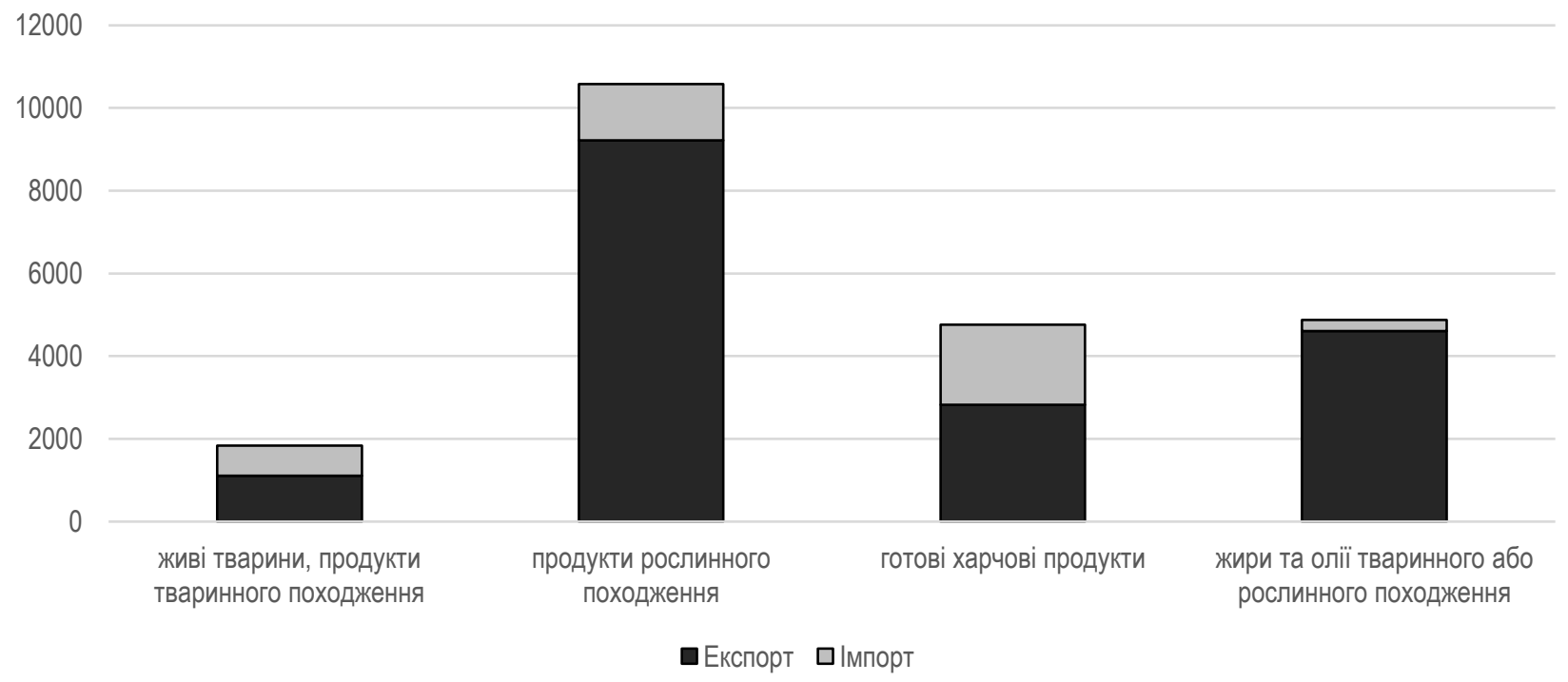

Рис. 5 - Структура експорту та імпорту сільськогосподарської продукції у 2017 році (Україна), млн дол

Джерело: власна розробка на базі даних Державної служби статистики України

у 2017 році польський експорт продовольства та живих тварин становив 96949 млн злотих, а імпорт - 88 0078,4 млн злотих, тваринні та рослинні олії, жири та воски - 1337,8 млн злотих експорту та 65 838,1 млн злотих імпорту. Відпо- відно, у Польщі імпорт сільськогосподарської продукції переважає експорт.

Порівняння експорту та імпорту сільськогосподарської продукції із загальним експортом та імпортом України та Польщі наведено в таблиці 4.

Таблиця 4. Порівняння української та польської структури експорту та імпорту сільськогосподарської продукції у 2017 році

\begin{tabular}{|l|l|r|r|}
\hline \multirow{5}{*}{ Україна } & \multicolumn{1}{|c|}{ Сільськогосподарська продукція } & \multicolumn{1}{|c|}{ Частка в експорті, \% } & \multicolumn{1}{c|}{ Частка в імпорті, \% } \\
\hline & Живі тварини, продукти тваринного походження & $2,6 \%$ & $1,5 \%$ \\
\cline { 2 - 4 } & Продукти рослинного походження & $21,3 \%$ & $2,8 \%$ \\
\cline { 2 - 4 } & Готові харчові продукти & $6,5 \%$ & $3,9 \%$ \\
\cline { 2 - 4 } & Жири та олії тваринного або рослинного походження & $10,6 \%$ & $0,5 \%$ \\
\hline \multirow{2}{*}{ польща } & Готові харчові продукти та живі тварини & $10,98 \%$ & $7,48 \%$ \\
\cline { 2 - 4 } & Жири та олії тваринного або рослинного походження, воски & $0,14 \%$ & $0,41 \%$ \\
\hline
\end{tabular}

Джерело: власна розробка на базі даних Державної служби статистики України та Центрального статистичного офісу Польщі

В Україні овочева продукція займає друга місце за часткою в експорті (найбільший обсяг експорту займають метали та вироби з них -23,4\%).

3. Особливості сільськогосподарського комплексу України та тенденції його розвитку

У 2015 році Україна підписала угоду про асоціацію з
ЄС. У рамках якої українські аграрії отримали певні пільги та привілеї. Тим не менш, Україна також пообіцяла привести законодавство до вимог аграрного ринку в Європі, а українські аграрії повинні стандартизувати своє виробництво відповідно до вимог ЄС. Процес триває вже кілька років, багато вже 
зроблено, але обсягів для подальшої роботи вистачає. Залишається сподіватися, що українські аграрні підприємства не упустять можливості повноцінно вийти на європейський риHOK.

Визначимо також ще кілька особливостей та тенденцій розвитку аграрного ринку України:

1. Вплив коливань цін на ринку зерна та бобів. В останні роки українські аграрії постійно збільшують врожай зерна та бобових. Але використовувати його в повному обсязі неможливо через зниження цін на продукцію. Компенсувати вплив коливань цін можливо шляхом впровадження інноваційних підходів та технологій, переорієнтації на органічну продукцію тощо.

2. В Україні діє мораторій на продаж землі. Це питання регулярно піднімається, але більше як фрактор для політичних спекуляцій. Створення вільного ринку землі є важливим фрактором розвитку як сучасної ринкової економіки, так і сільського господарства.

3. Рейдерські захоплення сільськогосподарських підприємств (Пропозиція, 2019). Нестабільність судової та правоохоронної систем України дає можливість не тільки блокувати роботу успішних підприємств, а й навіть неправомірно ними заволодіти. I хоча рівень успішності налагодження роботи після рейдерських захоплень постійно зростає, а їхня кількість зменшується, цей фактор все ще має сильний вплив у межах аграрної сфрери в Україні.

4. Особливості аграрних підприємств України (Цибульська, 2017). 3 огляду на історичні особливості розвитку аграрного сектора, українські підприємства характеризуються закритістю від зовнішнього світу, складною структурою управління і комунікації, відсутністю стратегії розвитку, нездатністю шукати інформацію, аналізувати ринок, подавати свою компанію іноземним партнерам.

5. Експорт курятини на європейський ринок (Livingstone, 2019). Хоча Європейський союз під тиском місцевих виробників перекрив юридичну можливість, яка дозволяла українським виробникам експортувати курячі грудки з кістками всередині (які з того часу почали називати «розріз Бетмена») та уникати тарифів, оскільки продукт відрізнявся від курячого філе. Європейський союз має намір збільшити квоту на імпорт курячого філе з України з 20 тис. тонн до 50 тис. тонн, за одними даними, або навіть до 70 тис. тонн за іншими. Варто відзначити, що в 2015 році українські виробники не експортували куряче філе в Європу взагалі, а вже в 2017 році експорт сягнув 27 тис. тонн. Тому така зміна квоти стане досить перспективною.

6. Нарощування експорту аграрної продукції в Люксембург (Прес-служба Мінекономрозвитку, 2019). Зараз ведуться переговори про укладення міжурядової угоди про економічне співробітництво між Україною і Люксембургом. Це дозволить Україні збільшити експорт. Тільки в 2018 році товарообіг між країнами склав майже 90 млн дол. США. Також Люксембург входить до ТОП-10 інвесторів України. У цьому контексті Україна зацікавлена в експорті зернових і зернобобових культур в Люксембург.

7. Збільшення експорту томатної пасти в Європу (АгроПортал, 2019). Сьогодні в Україні в ссрері виробництва томатної пасти працює 38 підприємств. Україна займає 10 місце в світі і 3 місце в Європі за обсягом виробництва томатної пасти. Обсяг ринку томатної пасти в Європі - 1 млн тонн. Тому українські виробники просять ЄС та український уряд збільшити безмитну квоту на ввезення томатної пасти з 13 тис. тонн до 50 тис. тонн. Це дозволить знизить ціну на продукцію і зробить її більш конкурентоспроможною на європейському ринку.

\section{Висновки.}

Сільськогосподарський сектор відіграє більш важливу роль в економіці України, ніж Польщі. Хоча зараз показники аграрного сектору у Польщі значно вищі (з урахуванням доданої вартості, рівня зарплат тощо). Українські виробники мають значний потенціал з огляду на природні особливості країни.

Асоціація з ЄС відкриває значні перспективи для українських аграрних підприємств. Лише потрібні підтримка 3 боку уряду та бажання самих аграріїв їх використовувати.

Проведене дослідження стане основою для подальшого аналізу конкурентоспроможності сільськогосподарських підприємств України та пошуку шляхів його підвищення.

\section{Список ліmepamypu:}

1. Agroinsider (2019). EU transfers of laser which allowed MHP to improve supply of chicken. Retrieved from https://agroinsider.com.ua/2019/03/15/yes-perekriye-lazivku-yaka-dozvolila-mxp-narostiti-postavki-kuryatini/.

2. AgroPortal (2019). Agrarians are asked to increase euroquats for tomato paste almost 4 times. Retrieved from http://agroportal.ua/news/ukraina/agrarii-prosyat-uvelichit-evrokvoty-na-tomatnuyu-pastu-pochti-v-4-raza/.

3. Burachek, I., \& Mykhailenko, N. (2018). Modern condition and perspective directions of agricultural development in Ukraine. Global and National Problems of Economy, 21, 134-137. Retrieved from http://global-national.in.ua/archive/21-2018/27.pdf.

4. Danko, Yu. (2016). Innovative Approaches to Ensuring the Competitiveness of Small Agricultural Enterprises. The problems of economy,(3), 153-158. Retrieved from http://www.problecon.com/export_pdf/problems-of-economy-2016-3_0-pages153_158.pdf.

5. Korchun, V. (2013). Agricultural policy in Poland and Ukraine: Using of the polish experience in European integration of Ukraine. Scientific Bulletin of the Lesia Ukrainka Eastern European National University,(10), 172-180.

6. Kovalchuk, S. (2016). European orientiri of agrarian sphere of Ukraine: Prospects and possibilities. Economy and Society,(2), 54-60. Retrieved from http://economyandsociety.in.ua/eng/journal-2/9-articles-2/39-kovalchuk-s-ya.

7. Livingstone, E. (2019). Chicken Kiev baron on course for big EU trade win. Retrieved from https://www.politico.eu/article/yuriy-kosyuk-ukraine-chicken-kiev-baron-on-course-for-big-eu-trade-win/.

8. Minfin. (2018). NBU rate - euro (EUR). Retrieved from https://minfin.com.ua/ua/currency/nbu/eur/2018-12-03/2018-12-28/.

9. Narodowy Bank Polski. (2018). Middle exchange rates archive. Retrieved from

https://www.nbp.pl/homen.aspx?navid=archen\&c=/ascx/TabArchAen.ascx\&n=18a170en.

10. Official site of the State Statistics Service of Ukraine. Retrieved from http://ukrstat.gov.ua/.

11. Official site of the State Statistics Service of Poland. Retrieved from https://stat.gov.pl/. 
12. Proposition. (2019). Year 2018: New record and new challenges. Retrieved from https://propozitsiya.com/ua/rik-2018-ynovyy-rekord-i-novi-problemy.

13. Rijswick, C. (2018). World Vegetable Map 2018: More than Just a Local Affair. Retrieved from https://research.rabobank.com/far/en/sectors/regional-food-agri/world_vegetable_map_2018.html.

14. Salkova, I., Glovyuk, A., \& Oleksiienko, O. (2016). Measures To Ensure The Development Of Agriculture Of Ukraine In Terms Of European Integration. Agrosvit,(9), 45-50. Retrieved from http://www.agrosvit.info/?op=1\&z=2177\&i=8.

15. The Press Service of the Ministry of Economic Development and Trade (2019). Stepan Kubiv in Luxembourg met with Romain Schneider, Minister of Social Policy, Agriculture, Winemaking and Land Development. Retrieved from https://bit.ly/2Fvjl8i.

16. The World Bank. (n.d.). Agricultural land (sq. km). Retrieved from https://data.worldbank.org/indicator/AG.LND.AGRI.K2.

17. The World Bank. (n.d.). Agricultural land $(\%$ of land area). Retrieved from https://data.worldbank.org/indicator/AG.LND.AGRI.ZS.

18. The World Bank. (n.d.). Agriculture, forestry, and fishing, value added per worker (constant 2010 US\$). Retrieved from https://data.worldbank.org/indicator/NV.AGR.EMPL.KD.

19. The World Bank. (n.d.). Agriculture, forestry, and fishing, value added ( $\%$ of GDP). Retrieved from https://data.worldbank.org/indicator/NV.AGR.TOTL.ZS.

20. The World Bank. (n.d.). Cereal yield (kg per hectare). Retrieved from https://data.worldbank.org/indicator/AG.YLD.CREL.KG.

21. The World Bank. (n.d.). Land under cereal production (hectares). Retrieved from https://data.worldbank.org/indicator/AG.LND.CREL.HA.

22. Tsybulskaia, S. (2017). Master-class on development of export direction of agro enterprises. Retrieved from https://propozitsiya.com/ua/master-klass-iz-rozvitku-eksportnogo-napryamku-agropidpriiemstv.

23. United States Department of Agriculture (2019). Grain: World Markets and Trade. Retrieved from https://apps.fas.usda.gov/psdonline/circulars/grain.pdf.

24. United States Department of Agriculture (2019). Oilseeds: World Markets and Trade. Retrieved from https://apps.fas.usda.gov/psdonline/circulars/oilseeds.pdf.

25. Zakharchuk, O. (2015). Experience of agricultural development in Poland. The Economy of Agro-Industrial Complex, (10), 59-65. Retrieved from http://eapk.org.ua/en/contents/2015/10/59.

26. Zinchuk, T. (2016). Agri-Food Potential of Cooperation between Ukraine and Poland. Zeszyty Naukowe Uczelni Vistula, 47(2), 285-300. Retrieved from http://cejsh.icm.edu.pl/cejsh/element/bwmeta1.element.desklight-514a6eb5-3d3e-4e18-add5d9dfb4e12267.

Golysheva I.O., PhD, Associate Professor, Sumy National Agrarian University (Sumy, Ukraine)

Competitiveness analysis of agricultural complexes of Ukraine and Poland

In modern economic conditions, the success of national economy depends on the consistent management actions of its leaders and on the effective development of its separate enterprise subjects. Each country chooses its own economic sphere in which it can achieve the highest results. Such area for Ukraine is the market for agricultural products. Not the first year Ukraine is one of the world leading exporters of wheat, barley, corn, oats, rye, and oilseeds. Fertile lands and temperate climate give to the agrarian enterprises strong competitive advantages. Therefore, it is so important to help to realize the potential of the Ukrainian agrarian enterprises.

Poland has similar features of the territory and climate. Poland made huge races in economy development since association and EU membership. Therefore, comparison with the Polish agrarian complex is relevant for the analysis of competitiveness of the Ukrainian agrarian enterprises.

The main indicators of the agrarian sectors of Ukraine and Poland were analyzed in the article. Such indicators as agricultural land in absolute and relative terms, agriculture, forestry, and fishing value added were selected. In addition, the number of agricultural workers and their salaries in local currencies and in terms of euros, the dynamics of prices for major agricultural products and the structure of export-import of agricultural products were considered. Based on the analysis, the main features of the Ukrainian agrarian complex and its development trends were highlighted.

The agricultural sector plays a more significant role in the economy of Ukraine than Poland. Although now the indicators of the agrarian sector in Poland are significantly higher (taking into account the value added, the level of salaries and so on). Ukrainian producers have significant potential considering the natural features of the country.

The association with the EU opens up significant prospects for Ukrainian agrarian enterprises. The support from the government and the desire of the agrarians themselves to use them are only needed. The study will be the beginning for the analysis of the competitiveness of Ukrainian agricultural enterprises.

Key words: agricultural product, agricultural market, Ukraine, Poland, agricultural enterprise.

Дата надходження до редакції: 05.12.2018 р. 